Jurnal Kesehatan Masyarakat

\title{
Antioxidant Potential of Madura Knife Scallop (Solen $s p$ ) Extract as a Prevention of Oxidative Stress
}

Mirwa Adiprahara Anggarani ${ }^{\bowtie}$, Roy Januardi Irawan

Universitas Negeri Surabaya, Indonesia

Article Info

Article History:

Submitted June 2019

Accepted December 2019

Published March 2020

Keywords:

knife scallop, solvents,

antioxidant activity, IC50

DOI

https://doi.org/10.15294/

kemas.v15i3.19521

\begin{abstract}
Reactive Oxygen Species (ROS) are produced by humans as a result of cellular metabolism and environmental factors such as pollutants or cigarette smoke. ROS is a very reactive molecule and has the ability to damage cell structure. Oxidative stress is a condition between oxidants and antioxidants that is not balance, pathophysiologically, oxidative stress can trigger the risk of various diseases including hypertension, atherosclerosis, diabetes, heart failure, stroke and other chronic diseases. Oxidative stress can be overcome by intake of antioxidants. The purpose of this study was to determine the antioxidant activity contained in the meat and shells of a knife scallop (Solen sp.) that lives in Bangkalan waters, Madura. The method used in this study is an analysis of antioxidant activity with the DPPH method. Knife scallop has antioxidant activity which is evident from the IC50 values obtained. IC50 values of the shell and meat extract with ethanol solvent were $489.56 \mathrm{ppm}$ and $748.49 \mathrm{ppm}$. IC50 values of the shell and meat extract with ethyl acetate solvent were $916.43 \mathrm{ppm}$ and $2045.93 \mathrm{ppm}$. While the IC50 value of the shell and meat extract with chloroform solvent was $119.37 \mathrm{ppm}$ and $1692.80 \mathrm{ppm}$. Based on IC50 data of knife scallop shell and meat extracts on the 3 types of solvents, it can be concluded that knife scallop's shell and meat extract with ethanol solvent has the greatest antioxidant activity compared to ethyl acetate and chloroform solvents.
\end{abstract}

\section{Introduction}

Metabolic process that occur in cells can produce free radicals and reactive oxygen groups routinely (ROS) (Daniel et al., 2010; Urso, 2003). Oxidative stress is a condition caused by an imbalance between the production and accumulation of reactive oxygen species (ROS) in cells and tissues and the ability of biological systems to detoxify these reactive products (Pizzino, 2017). Oxidative stress can come from lifestyle such as inhaling cigarette smoke and excessive physical activity, which can trigger the risk of heart disease, diabetes and cancer (Droge, 2002). Oxidative stress can be overcome by antioxidants intake.

Antioxidants can be produced in our body (endogenous antioxidants) or received from outside (exogenous antioxidants). Examples of antioxidants are enzymes such as SOD, catalase, glutathione peroxidase, glutathione reductase; compounds such as reduced glutathione, minerals such as selenium, manganese, copper and zinc and vitamins such as vitamins A, C and E (Naregal, 2017). Antioxidants are compounds that can inhibit oxidation reactions, by binding to free radicals and highly reactive molecules. One form of reactive oxygen compounds is free radicals, these compounds are formed in the body and are triggered by various factors. Antioxidants both enzymatic and non-enzymatic are produced naturally in cells, these antioxidants have a role as a defense for cell organelles to deal with damage caused by free radicals (Evans, 
2000; Marciniak et al., 2009). Antioxidants have been used to inhibit the occurrence of free radicals, based on the source of antioxidants can be either synthetic antioxidants or natural antioxidants, synthetic antioxidants have side effects if used for a long period of time (Katrin, 2015). Therefore it is necessary to consider the use of natural antioxidants to avoid side effects if used in a long term period.

Natural products from bivalves and gastropods have been used as antioxidants, anti-bacterial anti-fungal, cytotoxic, anticancer, and enzyme inhibitors (Tadesse et al., 2008; Defer et al., 2009; Zhou et al., 2011). Some secondary metabolites of aquatic organisms show pharmacological activity (Pringgenies, 2010). Knife scallop (Solen sp), is a bivalves that is found in Indonesian waters.

Antioxidants are naturally contained in food from land and water. Food derived from the mollusk group contains many bioactive components that act as antioxidants. Types of mollusks that are known to contain antioxidants include marine leeches, ipong snails (Nurjanah et al., 2011), papaya snails (Suwandi et al., 2010) and kijing taiwan (Salamah et al., 2008).

Antioxidants are compounds that can inhibit oxidation reactions by binding to free radicals and molecules that are very reactive so that cell damage will be inhibited. Different types of antioxidants work together with normal cells and neutralize free radicals (Andayani et al., 2008). Antioxidants are inhibitors of the oxidation process even at relatively small concentrations, and have diverse physiological roles in the body (Kumar, 2011). Antioxidants used in biological systems function to regulate levels of free radicals so that damage to important molecules of the body does not occur and create a repair system needed to maintain the survival of cells (Milbury \& Richer, 2011). The human body naturally has an antioxidant system to counteract free radical reactivity on an ongoing basis, but if the amount of free radicals in the body are excessive, additional antioxidants are needed from food intake, namely vitamin $\mathrm{E}$, vitamin $\mathrm{C}$, flavonoids, and carotene (Erguder et al., 2007). According to Jin-Yeum et al., (2010), antioxidant action in biological systems, for example in plasma depends on several factors, namely the oxidant or ROS properties imposed on the biological system, the activity and amount of antioxidants, and the synergistic nature or interactions of antioxidants (Pietta, 2000)

Many studies show that flavonoids show biological activity, including antiallergenic, antiviral, anti-inflammatory, and vasodilation actions. However, much of the interest has been devoted to the antioxidant activity of flavonoids, which is caused by their ability to reduce the formation of free radicals and to scavenge free radicals. The capacity of flavonoids to act as antioxidants in vitro has been the subject of several studies in recent years, and important structural-activity relationships of antioxidant activity have been established. Many flavonoids have been shown to have antioxidant activity, free radical scavenging capacity, prevention of coronary heart disease, hepatoprotective, anti-inflammatory, and anticancer activities, while some flavonoids show potential antiviral activity. In factory systems, flavonoids help combat oxidative stress and act as growth regulators (Kumar, 2013).

Our body has the ability to neutralize or detoxify the harmful effects of ROS and keep it at optimal levels by compounds known as antioxidants. Antioxidants are produced in our body (endogenous antioxidants) or received from outside (exogenous antioxidants). Examples of antioxidants are enzymes such as SOD, catalase, glutathione peroxidase, glutathione reductase; compounds such as reduced glutathione; minerals such as selenium, manganese, copper and zinc and vitamins such as vitamins A, C, and E (Naregal, 2017).

Given the importance of the antioxidant function for the human body, we need a study of the antioxidant activity contained in knife scallop as a source of natural antioxidants. The purpose of this study was to determine the antioxidant activity of knife scallop which was extracted using various types of solvents, namely ethanol, ethyl acetate and chloroform.

\section{Method}

The study was conducted in January April 2019 at the Biochemistry Laboratory, Faculty of Mathematics and Natural Sciences, Surabaya State University. The main material in this study was the knife scallop (Solen sp.) obtained from the waters of Pamekasan Madura 
with a length of $2-5 \mathrm{~cm}$ and a width of $0.5-1 \mathrm{~cm}$. The meat was separated from the shell. Then the shell and the meat were dried in the sun for 5-7 days until a dry product with a moisture content of less than $12 \%$ was obtained. Then both were blended separately with a blender until each powder / flour of dried scallop meat and shell was obtained.

Active ingredient extraction was carried out according to the procedure of Quinn (1988) in Darusman et al., (1995). The extraction used the chloroform p.a (non-polar), ethyl acetate p.a. (semi-polar) and ethanol p.a. (polar), each of which had a different level of polarity. Extraction was done by maceration on each of $25 \mathrm{~g}$ of shell flour and meat flour in $100 \mathrm{ml}$ of ethanol solvent p.a. for 48 hours in an orbital shaker at $8 \mathrm{rpm}$. The filtrate obtained was evaporated using a rotary vacuum evaporator at $50{ }^{\circ} \mathrm{C}$.

The antioxidant activity test of each extract was carried out by the DPPH method (Blois 1985 in Hanani et al., 2005). Coarse knife scallop extract was dissolved in ethanol p.a. to obtain concentrations of 200, 400, 600 and 800 $\mathrm{ppm}$. Synthetic BHT antioxidant was used as a comparison and positive control is dissolved in the methanol solvent p.a. with concentrations of 2, 4, 68 and $10 \mathrm{ppm}$. DPPH solution was prepared by dissolving DPPH crystals in ethanol solvent p.a. with a concentration of 1 $\mathrm{mM}$. The process of making a $1 \mathrm{mM} \mathrm{DPPH}$ solution was carried out in low temperatures and protected from sunlight.
Antioxidant activity test was carried out on shell and knife scallop meat extracts. The extract solution and BHT antioxidant solution were each taken $4.50 \mathrm{ml}$ and reacted with 500 $\mu \mathrm{DPPH} 1 \mathrm{mM}$ solution in different test tubes. The reaction took place at $37^{\circ} \mathrm{C}$ for 30 minutes then the absorbance was measured using a UV-VIS spectrophotometer at a wavelength of $517 \mathrm{~nm}$. Absorbance of the blank solution was measured to calculate inhibition percentage. A blank solution was made by reacting $4.50 \mathrm{ml}$ of methanol solvent with $500 \mathrm{~mL}$ of $1 \mathrm{mM} \mathrm{DPPH}$ solution in a test tube. Antioxidant activity is expressed in inhibition percentage, which is calculated by the formula:

$\%$ inhibition $=\frac{\text { blank absorbance }- \text { sample absorbance }}{\text { blank absorbance }} \times 100 \%$

The sample concentration and inhibition percentage were plotted respectively on the $\mathrm{x}$ and $y$ axis in the linear regression equation. The equation then used to determine the IC50 value (inhibitor concentration 50\%) of each sample expressed with a y value of 50 and an $\mathrm{x}$ value that will be obtained as IC50. The IC50 value states the concentration of the sample solution (extract or BHT) needed to reduce DPPH free radicals by $50 \%$.

\section{Result and Discussion}

Antioxidant activity can be determined through an analysis of the antioxidants contained in shell and meat samples, using the DPPH method. The DPPH method is used

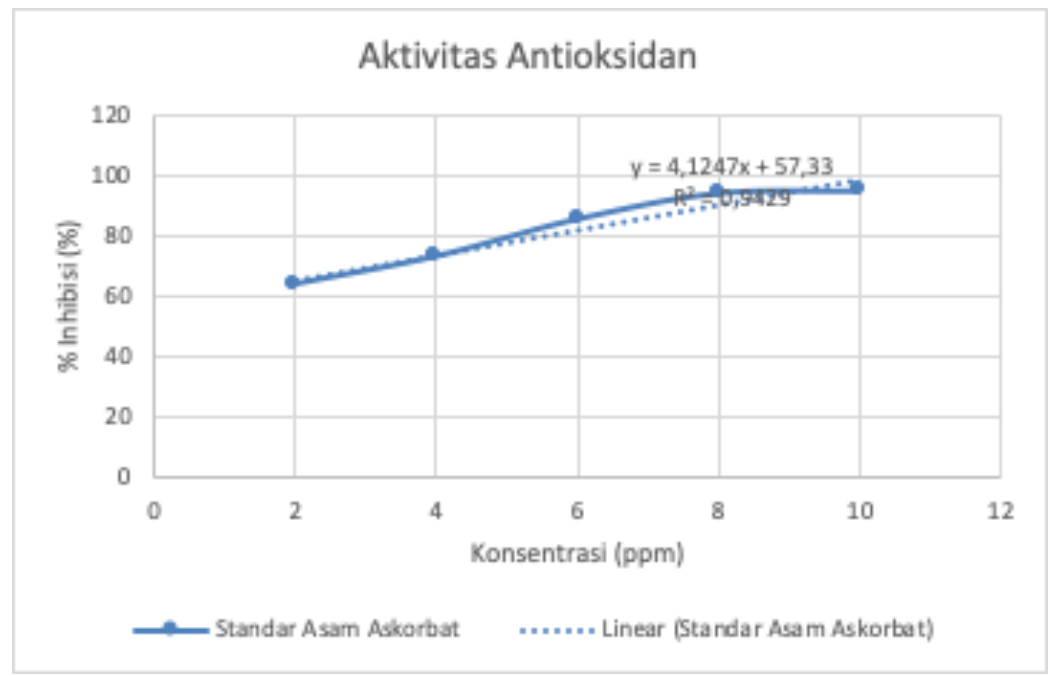

Image 1. Graphic of the Relation of Ascorbic Acid Concentration with Inhibition Percentage 


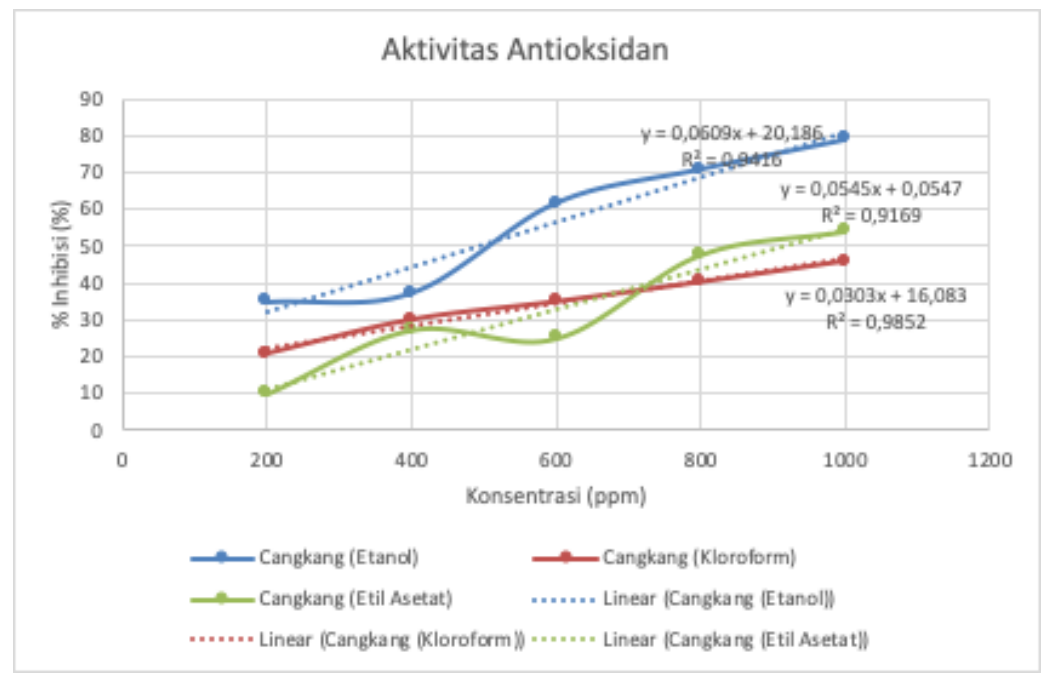

Image 2. Graph of the Relation of Shell Extract Concentration with Inhibition Percentage

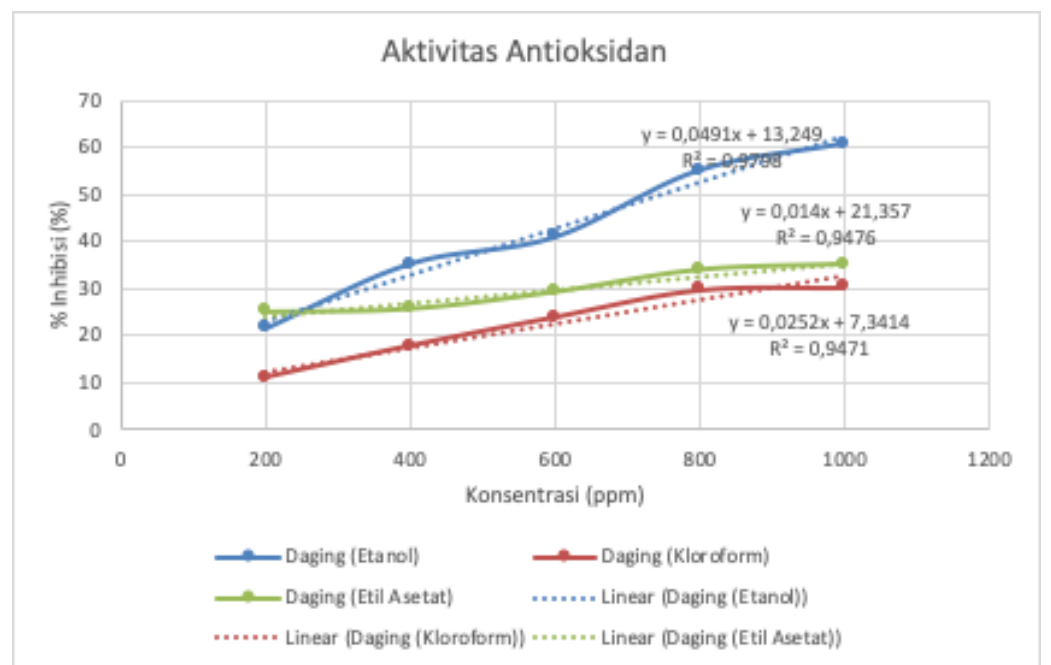

Image 3. Graph of the Relation of the Concentration of Meat Extract with Inhibition Percentage

because it only uses a small number of samples and a short testing period. The antioxidant compound used as a comparison is ascorbic acid.

In antioxidant testing, a relation between sample concentration (ppm) and inhibition percentage (\%) is shown in Image 1, Image 2, and Image 3.

Inhibition percentage is the ability of a compound to inhibit free radical activity, which is affected by the concentration of a compound (Yanuarizki, 2013). Based on Figure 1, Figure 2 , and Figure 3, we get a linear graph of the relation between concentration and percent inhibition, where the higher the concentration of a sample, the higher the percentage of inhibition in inhibiting antioxidant activity. The inhibition percentage value of ascorbic acid in this study were $63.79 \%, 72.97 \%, 85.23 \%$, $93.76 \%$, and $94.64 \%$, respectively. The increase in the value of inhibition percentage of ascorbic acid, also occurs in samples of knife scallop shell and meat.

Inhibitory Concentration $50\left(\mathrm{IC}_{50}\right)$ is defined as the concentration of antioxidant compounds that can cause a loss of $50 \%$ of DPPH activity. A compound is said to have a very strong antioxidant activity if the $\mathrm{IC}_{50}$ value is less than $50 \mathrm{ppm}$, strong if the $\mathrm{IC}_{50}$ value is between $50-100 \mathrm{ppm}$, medium if the IC50 value is $101-150 \mathrm{ppm}$, and weak if it is between 150 $200 \mathrm{ppm}$. The smaller the IC50 value, the greater 
Table 1. The Results of Antioxidant Activity Tests on Shell Extract and Meat Extract

\begin{tabular}{lllllll}
\hline \multirow{2}{*}{ Sample } & \multicolumn{2}{l}{ \% Inhibition } & & & & \multirow{2}{*}{$\mathrm{IC}_{50}$} \\
& $200 \mathrm{pm}$ & $400 \mathrm{ppm}$ & $600 \mathrm{ppm}$ & $800 \mathrm{ppm}$ & $1000 \mathrm{ppm}$ & \\
\hline Shell Ethanol & $34.79 \%$ & $37.31 \%$ & $61.71 \%$ & $70.90 \%$ & $78.88 \%$ & 489.56 \\
Shell Chloroform & $20.68 \%$ & $29.87 \%$ & $34.79 \%$ & $40.15 \%$ & $45.84 \%$ & 1119.37 \\
Shell Ethyl Acetate & $9.85 \%$ & $27.24 \%$ & $24.95 \%$ & $47.70 \%$ & $54.16 \%$ & 916.43 \\
Meat Ethanol & $21.55 \%$ & $35.23 \%$ & $40.91 \%$ & $55.03 \%$ & $60.72 \%$ & 748.49 \\
Meat Chloroform & $10.94 \%$ & $17.72 \%$ & $23.85 \%$ & $29.65 \%$ & $30.20 \%$ & 1692.80 \\
Meat Ethyl Acetate & $25.05 \%$ & $25.71 \%$ & $29.21 \%$ & $33.81 \%$ & $35.01 \%$ & 2045.93 \\
\hline
\end{tabular}

Source: Primary Data, 2019

the antioxidant activity (Yanuarizki, 2013).

IC50 value is even greater if the extract is dissolved in the solvent used less. This situation suggests the need for testing antioxidant activity using other testing methods that are more universal, both for bioactive components that are polar, semi polar, and non-polar. The DPPH test method is the method of testing antioxidant activity that is most suitable for polar antioxidant components, because DPPH crystals can only dissolve and provide maximum absorbance in ethanol or methanol solvents as suggested by Amrun \& Umiyah (2005).

Ethanol extract (polar) has bioactive components of alkaloids and flavonoids. The existence of this compound in ethanol extract is thought to play a role in reducing DPPH free radicals by tests carried out, thus giving a smaller IC50 value compared to chloroform and ethyl acetate extracts. The higher concentration of knife shell extract, it results in a high percentage of free radical inhibition. This is according to research conducted by Qian \& Nihorimbere (2004) stating the percentage of inhibition of free radical activity increases with increasing extract concentration.

Reactive oxygen species (ROS) are byproducts of normal cell activity. They are produced in many cellular compartments and play a major role in the signaling pathway. Over production of ROS is associated with the development of various human diseases (including cancer, cardiovascular, neurodegenerative, and metabolic disorders), inflammation, and premature aging (oxidative stress is a balance disorder between free radical production and endogenous antioxidant defense systems, which then results in the accumulation of oxidative damage, activation of signaling pathways that are sensitive to stress and the development of pathological conditions such as cardiovascular disease, insulin resistance, and metabolic syndrome (Anastasya, 2019) Free Radicals or Reactive Oxygen Species (ROS) can be prevented by antioxidants The body's mechanism of resistance to oxidative stress is through antioxidants endogenous: If the number of free radicals and reactive species in the body exceeds the ability of endogenous antioxidants, the body needs intake of antioxidants obtained from food or drugs (Werdhasari, 20014) .In addition, antioxidants can also be obtained from herbs and animals (antiok endogenous epidermis). Exogenous antioxidants mainly come from food and medicinal plants, such as fruits, vegetables, cereals, mushrooms, drinks, flowers, herbs and traditional medicinal herbs (Cai, 2014). Natural antioxidants from this plant material are mainly polyphenols (phenolic acids, flavonoids, anthocyanin, lignin and stilbene), carotene (xanthophyll and carotene) and vitamins (vitamins $\mathrm{E}$ and $\mathrm{C}$ ) (Manach, 2004). Some food ingredients that are believed to have antioxidant functions include gembili, yam, cassava, arrowroot, and kimpul (Soesilowati, 2018).

Antioxidants can be broadly defined as any substance that delays or inhibits oxidative damage to the target molecule (Yamagichi, 2011). The main characteristic of antioxidants is their ability to trap free radicals. Antioxidant compounds such as phenolic acids, polyphenols, and flavonoids look for free radicals such as peroxide, hydro peroxide or peroxyl lipids 
and thus inhibit oxidative mechanisms that lead to degenerative diseases $(\mathrm{Wu}, 2011)$. Generally, these natural antioxidants, especially polyphenols and carotenoids, exhibit various biological effects, such as anti-inflammatory, antibacterial, antiviral, anti-aging, and anticancer properties (Jenab, 2006).

Flavonoid is an important class of natural products, flavonoid is included in the secondary metabolite class of plants that have a polyphenol structure, the compound is mostly found in fruits, vegetables and certain beverages. Flavonoid is believed to have various beneficial biochemical and antioxidant effects associated with various diseases such as cancer, Alzheimer's, atherosclerosis (Panche, 2016). Flavonoid can prevent cardiovascular disease by reducing the rate of fat oxidation, because of its role as an antioxidant. Some research results show that flavonoid can reduce hyperlipidemia in humans. Inhibition of LDL oxidation in cases of heart disease by flavonoid can prevent the formation of foam cells and lipid damage. Flavonoid also has functions as anti-bacterial, anti-inflammatory, anti-tumor, anti-allergic, and prevent osteoporosis (Al-Meshal et al., 1985).

Nurjanah et al., (2011) research results on testing the antioxidant activity of knife scallop using the DPPH method, showed that the $\mathrm{IC}_{50}$ value of chloroform extract was 2008.52 ppm, ethyl acetate extract was $1593.87 \mathrm{ppm}$ and methanol extract was $1391.08 \mathrm{ppm}$. When compared with the results of this study, the antioxidant activity produced is smaller. $\mathrm{IC}_{50}$ values of knife scallop's shell and meat extract with ethanol solvent in this study were 489.56 ppm and $748.49 \mathrm{ppm}$. These results are much smaller than the results of research Nurjanah et al., (2011). It is caused by the type of solvent used in the maceration method which is one type of solvent namely ethanol. In addition, this study conducted a separation of meat and shells to determine between the two parts which were more potential as anti-oxidant.

\section{Conclussion}

Scallop's shell and meat extract with ethanol solvent have greater antioxidant activity than with other solvents, which had a small $\mathrm{IC}_{50}$ value of $489.56 \mathrm{ppm}$ and $748.49 \mathrm{ppm}$. The antioxidant activity of scallop's shell and meat extract with various solvents using the DPPH method, were relatively weak by the standard used due to the $\mathrm{IC}_{50}$ value of samples greater than $200 \mathrm{ppm}$. This was presumably because the scallop's extract used in this study was still classified as crude extract and was suspected to still contain other compounds that affected the antioxidant activity and was extracted in the solvent during the extraction process.

\section{Suggestion}

Based on the results of this study, suggestions that can be given include (1) The need for further research on the role of knife scallop as natural antioxidants, (2) need to involve living creature in further research to obtain data on the potential extract of knife scallop as natural antioxidant.

\section{References}

Al-Meshal, I.A., M. Tariq, N.S. Parmar, \& A.M.Ageel. 1985. Anti inflammatory activity of the flavonoid fraction of khat (Catha edulis Forsk). Agents and Actions, 17:3-4.

Anastasiya V. Snezhkina, Anna V. Kudryavtseva, Olga L. Kardymon, et al., "ROS Generation and Antioxidant Defense Systems in Normal and Malignant Cells," Oxidative Medicine and Cellular Longevity, vol. 2019, Article ID 6175804, 17 pages, 2019

Amrun, M.H. \& Umiyah. 2005. Pengujian anti radikal bebas difenilpikril hidrazil (DPPH) ekstrak buah kenitu (Chrysophyllum Cainito L.) dari daerah Jember. J. Ilmu dasar, 6(2):110-114.

Andayani, R., L. Yovita, \& Maimunah. 2008. Penentuan aktivitas antioksidan, kadar fenolat total dan likopen pada buah Tomat (Solanum lycopersium 1). J. Sains dan teknologi farmasi, 13(1):31037.

Cai Y.Z., Luo Q., Sun M., Corke H. Antioxidant activity and phenolic compounds of 112 traditional Chinese medicinal plants associated with anticancer. Life Sci. 2004;74:2157-2184

Daniel, R.M., Stelian, S., Dragomir, C. (2010), The effect of acute physical exercise on the antioxidant status of the skeletal and cardiac muscle in the Wistar rat. Romanian Biotechnological Letters.

Darusman, L.K, Sajuti, D., Komar, \& Pamungkas. 1995. Ekstraksi komponen bioaktif sebagai obat dari kerang-kerangan, bunga karang dan ganggang laut di Perairan Pulai Pari Kepulauan Seribu. Buletin Kimia,.2:41-60.

Defer, D., N. Bourgougnon, \& Y. Fleury. 2009. 
Screening for antibacterial and antiviral activities in three bivalve and two gastropod marine molluscs. J. Aquaculture, 293: 1-7.

Droge W. Free radicals in the physiological control of cell function. Physiological Reviews. 2002;82:47-95

Erguder, B., A. Avci, E. Devrim, \& I. Durak. 2007. Effects of cooking techniques on antioxidant enzyme activities of some fruits and vegetables. Turk. J. Med. Sci., 37(3):151-156.

Evans, W. J. (2000), Vitamin E, vitamin C, and exercise. Am J Clin Nutr, 72, 647S-52S

Katrin, Bendra A. 2015. Aktivitas Antioksidan Ekstrak, Fraksi dan Golongan Senyawa Kimia Daun Premna oblongata Miq. Pharm Sci Res. April 2015; 2 (1)

Kumar, S. 2011. Free radicals and antioxidants: human and food system. Adv. In Appl. Sci. Res., 2(1):129-135.

Kumar, S., Pandey, A.K. 2013. "Chemistry and Biological Activities of Flavonoids: An Overview," The Scientific World Journal, vol. 2013, Article ID 162750, 16 pages, 2013

Jenab M., Riboli E., Ferrari P., Sabate J., Slimani N., Norat T., Friesen M., Tjonneland A., Olsen A., Overvad K., et al. Plasma and dietary vitamin $\mathrm{C}$ levels and risk of gastric cancer in the European Prospective Investigation into Cancer and Nutrition (EPICEURGAST) Carcinogenesis. 2006;27:22502257.

Jin-Yeum, K.J., N.U. Russell, A. Majid, M. Fiaz, \& A.H. Shah. 2010. Antibacterial activity of some medicinal mangroves against antibiotic resistant pathogenic bacteria. Indian $J$. Pharmacue. Sci., 72(2):167-172.

Manach C., Scalbert A., Morand C., Remesy C., Jimenez L. Polyphenols: Food sources and bioavailability. Am. J. Clin. Nutr. 2004;79:727-747

Marciniak, A., Brzeszczynska, J., Gwozdzinski, K., Jegier, A. (2009), Antioxidant Capacity and Physical Exercise. Biology of Sport, Vol. 26 No3, 197-213

Milbury, P.E., \& A.C. Richer. 2011. Understanding the antioxidant controversy: Scrutinizing the 'fountain of youth'. Greenwood Publishing Group. USA.

Naregal GV, Devaranavadagi BB, Patil SG, Aski BS. Elevation of Oxidative Stress and Decline in Endogenous Antioxidant Defense in Elderly Individuals with Hypertension. J Clin Diagn Res. 2017;11(7):BC09-BC12. doi:10.7860/ JCDR/2017/27931.10252

Nurjanah, A. Abdullah, \& A. Apriand. 2011. Aktivitas antioksidan dan komponen bioaktif pada keong ipong-ipong (Fasciolaria salmo). J. Pengolahan Hasil Perikanan Indonesia, $\mathrm{XIV}(1): 22-29$.

Nurjanah, L. Izzati \& A. Abdullah. 2011. Aktivitas antioksidan dan komponen biokatif Kerang Pisau (Solen sp). J. Pengolahan Hasil Perikanan Indonesia, XVI(3):119-124.

Panche, A.N., Diwan A.D., Chandra A.R., Flavonoids: an overview. J Nutr Sci. 2016; 5; e47.

Pietta, PG. 2000. Flavonoids as antioxidabts. J Nat Prod 2000 Jul; 63(7): 1035-42.

Pizzino G., Irrera N., Cucinotta M., Pallio G., Mannino F., Arcoraci V., Squardrito F., Altavilla D., Bitto A. 2017. Oxidative Stress: Harms and Benefits for Human Health. Oxid Med Cell Longev. 2017; 2017: 8416763.

Pringgenies, D. 2010. Karakteristik senyawa bioaktif bakteri simbion moluska dengan Gc-MS. J. Ilmu dan teknologi Kelautan Tropis, 2(2): 3440.

Qian,H., \& V. Nihorimbere. 2004. Antioxidant power of phytochemicals from osidium guajava leaf. J. Zeijang Univ. Sci., 5(6):676683.

Salamah, E., E. Ayuningrat, \& S. Purwaningsih. 2008. Penapisan awal komponen bioaktif dari Kijing Taiwan (Anadonta woodiana Lea.) sebagai senyawa antioksidan. Buletin Teknologi Hasil Perikanan, 11(2):119-132.

Soesilowati, E., Martuti, NKT., Paramita, O. Improvement of Nutritional Quality of Tuber Flour as Local Food Resource. KEMAS 14 (1) (2018) 99-105.

Suwandi, R., Nurjanah, \& F. Naryuningtias. 2010. Aktivitas antioksidan dan komponen bioaktif dari keong papaya (Melos sp). Akuatik, 4(2):16-20.

Tadesse, M., B. Gulliksen, M.B. Strim, O.B. Styrvoid, \& T. Haug. 2008. Screening for antibacterial and antifungal activities in marine benthic invertebrates from northern Norway. J. Invertebrate Pathology, 99: 286-293.

Urso, M.L., Clarkson, P.M. (2003), Oxidative stress, exercise, and antioxidant supplementation. Toxicology 189(1-2):41-54

Werdhasari, A. 2014. Peran Antioksidan Bagi Kesehatan. Jurnal Biotek Medisiana Indonesia. Vol.3.2.2014: 59-68.

Wu YY, Li W, Xu Y, Jin EH, Tu YY. Evaluation of the antioxidant effects of four main theaflavin derivatives through chemiluminescence and DNA damage analyses. J Zhejiang Univ Sci B. $2011 ; 12: 744-75$

Yamagishi S, Matsui T. Nitric oxide, a Janusfaced therapeutic target for diabetic microangiopathy-Friend or foe? Pharmacol 
Res. 2011;64:187-194

Yanuarizki, Ovintya. 2013. Aktivitas antioksidan dan komponen bioaktif Kerang Simping (Amusium pleuronectes). Skripsi. Bogor: Departemen Teknologi Hasil Perairan, Fakultas Perikanan dan Ilmu Kelautan, IPB.
Zhou, D.Y., Zhu, L. Qiao, H.T. Wu, D.M. Li, J.F. Yang, \& Y. Murata. 2011. In vitro antioxidant activity of enzymatic hydrolysates prepared from abalone (Haliotis discus hannai Ino) viscera. Food and Bioproducts Processing, in press. 